\title{
On the relationship between palaeomagnetic secular variation and excursions-records from MIS 8-ODP Leg 172
}

\author{
Steve Lund ${ }^{\oplus},{ }^{1}$ Gary Acton, ${ }^{2}$ Brad Clement, ${ }^{2}$ Makoto Okada ${ }^{3}$ and Lloyd Keigwin ${ }^{4}$ \\ ${ }^{1}$ Department of Earth Sciences, University of Southern California, Los Angeles, CA 90089, USA. E-mail: slund@usc.edu \\ ${ }^{2}$ International Ocean Discovery Program, Texas A\&M University, College Station, TX 77845, USA \\ ${ }^{3}$ Department of Geology, Ibaraki University, Mito, Ibaraki-ken, Japan \\ ${ }^{4}$ Wood Hole Oceanographic Institution, Woods Hole, MA 02543-1050, USA
}

Accepted 2020 November 18. Received 2020 November 1; in original form 2020 April 29

\begin{abstract}
SUMMAR Y
Palaeomagnetic secular variation (PSV) and excursion data obtained across MIS 8 (243$300 \mathrm{ka}$ ) from the western North Atlantic Ocean ODP (Ocean Drilling Program) sites 1060-1063 show composite high-resolution PSV records (both directions and relative palaeointensity) developed for each site and intercompared. Two methods of chronostratigraphy allow us to date these records. First, we used published results that compared the calcium carbonate records of ODP Leg 172 sediments and tuned them with Milankovich cyclicity. We also compared our palaeointensity records with the PISO-1500 global palaeointensity record that was dated with oxygen isotope stratigraphy. We prefer the PISO-1500 record to date our cores. Two excursions are preserved in our PSV records-Excursions $8 \alpha$ and $9 \alpha$. Our revised age estimates for both excursions are $8 \alpha(236.7-239.8 \mathrm{ka})$ and $9 \alpha(283.7-286.9 \mathrm{ka})$. We have compared shipboard measurements of the two excursions with u-channel measurements of selected excursion intervals. Excursion $8 \alpha$ is interpreted as a 'Class II' excursion (local reversal) with in-phase inclination and declination changes; Excursion $9 \alpha$ is a 'Class I' excursion with $90^{\circ}$ out-of-phase inclination and declination changes. Averaged directions (after removal of true excursional directions) and relative palaeointensity in 3 and 9 ka overlapping intervals show significant PSV directional variability over $10^{4} \mathrm{yr}$ timescales that is regionally correlatable among the four sites. A notable pattern of angular dispersion variability involves most time spent with low $\left(\sim 10^{\circ}\right)$ dispersion, with three shorter intervals of high $\left(\sim 25^{\circ}\right)$ dispersion. The relative palaeointensity variability also shows significant variability over $10^{4} \mathrm{yr}$ timescales with three notable intervals of low palaeointensity in all four records and a direct correspondence between the three low-palaeointensity intervals and the three intervals of high angular dispersion. The two magnetic field excursions occur in two of the three low-palaeointensity/high-dispersion intervals. This suggests that the geomagnetic field operates in two states between reversals, one with regular to high palaeointensity and low directional variability and one with low palaeointensity and significantly higher directional variability and excursions.
\end{abstract}

Key words: Geomagnetic excursions; Palaeointensity; Palaeomagnetic secular variation.

\section{INTRODUCTION}

Palaeomagnetic secular variation (PSV) records describe the normal pattern of geomagnetic field variability between global field reversals. The last such reversal (Brunhes/Matuyama boundary) occurred about $780000 \mathrm{yr}$ ago and the normal-polarity interval of PSV that has occurred since then is referred to the Brunhes Chron (Merrill et al. 1998). PSV is a full-vector process that is a combination of directional variability (inclination and declination) and intensity variability. Within the Brunhes Chron, there is evidence of more than
10 intervals of anomalous palaeomagnetic field directional behaviour, often termed excursions, which have occurred intermittently and locally at various places around the world (e.g. Champion et al. 1988; Langereis et al. 1997; Lund et al. 1998, 2001a, 2006). There is, however, no clear understanding of what happens on a global scale during any one of these excursions and there is similarly no clear understanding of what is the local relationship between 'anomalous' excursions and the surrounding 'normal' PSV.

Ocean Drilling Program (ODP) Leg 172 recovered complete records of Brunhes Chron deep-sea sediments from nine sites (sites 
Table 1. Chronostratigraphy and sedimentation rates (SR) of ODP Leg 172 sites during MIS 8 (243-300 ka).

\begin{tabular}{|c|c|c|c|c|c|c|c|c|}
\hline $\begin{array}{l}\text { Grutzner age }(\mathrm{ka}) \\
\text { (tuned/phase-shifted) }\end{array}$ & $\begin{array}{l}1060 \\
\text { (mcd) }\end{array}$ & $\begin{array}{c}1060-\mathrm{SR} \\
\left(\mathrm{cm} \mathrm{kyr}^{-1}\right)\end{array}$ & $\begin{array}{l}1061 \\
(\mathrm{mcd})\end{array}$ & $\begin{array}{c}1061-\mathrm{SR} \\
\left(\mathrm{cm} \mathrm{kyr}^{-1}\right)\end{array}$ & $\begin{array}{l}1062 \mathrm{E} \\
\text { (mcd) }\end{array}$ & $\begin{array}{c}1062-\mathrm{SR} \\
\left(\mathrm{cm} \mathrm{kyr}^{-1}\right)\end{array}$ & $\begin{array}{l}1063 \\
\text { (mcd) }\end{array}$ & $\begin{array}{c}1063-\mathrm{SR} \\
\left(\mathrm{cm} \mathrm{kyr}^{-1}\right)\end{array}$ \\
\hline $242.8 / 237.8$ & 78.4 & & 71.44 & & 43.82 & & 60 & \\
\hline Interval ave & & 15.1 & & 16.7 & & 14 & & 13.6 \\
\hline Interval ave & & 38.3 & & 37.4 & & 17.8 & & 18.4 \\
\hline 278.8273 .8 & 87.06 & & 80.29 & & 49.3 & & 65.79 & \\
\hline Interval ave & & 34.3 & & 39.8 & & 17.5 & & 22 \\
\hline $312.8 / 307.8$ & 97.18 & & 91.07 & & 54.43 & & 71.75 & \\
\hline Overall ave & & 28.325 & & 29.725 & & 15.55 & & 16.95 \\
\hline MIS 7/8 (243) & 78.4 & & 71.5 & & 43.85 & & 60.1 & \\
\hline Interval ave & & 27.2 & & 28.8 & & 15.7 & & 17.4 \\
\hline MIS 8/9 (300) & 93.9 & & 87.9 & & 52.8 & & 70 & \\
\hline PINT age (ka) & $\begin{array}{l}1060 \\
(\mathrm{mcd})\end{array}$ & $\begin{array}{c}1060-\mathrm{SR} \\
\left(\mathrm{cm} \mathrm{kyr}^{-1}\right)\end{array}$ & $\begin{array}{l}1061 \\
(\mathrm{mcd})\end{array}$ & $\begin{array}{c}\text { 1061-SR } \\
\left(\mathrm{cm} \mathrm{kyr}^{-1}\right)\end{array}$ & $\begin{array}{l}1062 \mathrm{E} \\
(\mathrm{mcd})\end{array}$ & $\begin{array}{c}\text { 1062-SR } \\
\left(\mathrm{cm} \mathrm{kyr}^{-1}\right)\end{array}$ & $\begin{array}{l}1063 \\
(\mathrm{mcd})\end{array}$ & $\begin{array}{c}\text { 1063-SR } \\
\left(\mathrm{cm} \mathrm{kyr}^{-1}\right)\end{array}$ \\
\hline Interval ave & & 15 & & 15 & & 14 & & 12 \\
\hline $23-249$ & 80.3 & & 73.3 & & 45.7 & & 61.8 & \\
\hline Interval ave & & 12 & & 16 & & 11 & & 13 \\
\hline $24-259$ & 81.5 & & 74.9 & & 46.8 & & 63.1 & \\
\hline Interval ave & & 83.7 & & 85 & & 38.7 & & 43.7 \\
\hline $25-267$ & 88.2 & & 81.7 & & 49.9 & & 66.6 & \\
\hline Interval ave & & 29.4 & & 33.5 & & 13.5 & & 17.6 \\
\hline $26-284$ & 93.2 & & 87.4 & & 52.2 & & 69.6 & \\
\hline Interval ave & & 17.8 & & 17 & & 12.3 & & 10 \\
\hline $27-297$ & 95.5 & & 89.6 & & 53.8 & & 70.8 & \\
\hline Interval ave & & 14.2 & & 11.4 & & 10 & & 10 \\
\hline $28-304$ & 96.5 & & 90.4 & & 54.1 & & 71.4 & \\
\hline
\end{tabular}

1054-1063) in the western subtropical North Atlantic Ocean (Keigwin et al. 1998). At four of these sites (1060-1063), replicate records of Brunhes-aged PSV and excursions were recovered from shipboard measurements (Lund et al. 1998, 2001a). This contribution is one of a series of papers that characterize the PSV in selected Brunhes Chron intervals surrounding these excursions as recorded in the sediments of ODP Leg 172. The overall purpose is to understand the long-term variability in PSV and the relationship of that variation to the occurrence and behaviour of excursions. These papers will also improve the chronology and relative timing of PSV and excursions so that comparative analyses of these same time intervals can be developed from several global localities (e.g. Lund 2018). Such detailed chronostratigraphic analysis will fundamentally improve our understanding of the space/time pattern of excursions and PSV (as well as, perhaps, climate variability). The focus of this paper is PSV records from MIS 8 (243-300 ka), which includes Excursion $8 \alpha$ as originally described by Lund et al. (1998, 2001a).

There is evidence for the existence of two or three excursions in the MIS 8 time interval (243-300 ka). Wollin et al. (1971) were the first to indicate the existence of an excursion near $275 \pm 15 \mathrm{ka}$ in deep-sea sediment cores from the Caribbean Sea, North Atlantic Ocean, Mediterranean Sea and North Pacific Ocean. Soon after that, Kawai et al. (1972) noted an excursion, which they named Biwa II, in Lake Biwa, Japan, that was dated at 292-298 ka.
Creer et al. (1980) identified an excursion, named $\alpha$, in uplifted marine sediments from Gioia Tauro, Italy, at $\sim 290 \mathrm{ka}$. However, we will ignore that result because the data come only from inclinations, do not reach negative values and have poor chronology. Nowaczyk \& Baumann (1992) identified an excursion that they called Biwa II at $\sim 260 \mathrm{ka}$ in the high-latitude North Atlantic Ocean (Fram Strait). Later, Nowaczyk et al. (1994) identified two excursions in this time interval, one at $\sim 250 \mathrm{ka}$ and the other at $\sim 280 \mathrm{ka}$ from deep-sea sediments north of Iceland. They called the older excursion the Biwa II event. Langereis et al. (1997) identified one excursion in this interval from the Mediterranean Sea near $261 \pm 3 \mathrm{ka}$, which they named CR0. Keigwin et al. (1998) and Lund et al. (1998, 2001a) identified two excursions in this interval $-8 \alpha$ at $260 \pm 20 \mathrm{ka}$ and $9 \alpha$ at $300 \pm 10 \mathrm{ka}$. In this paper, we have redefined their ages to be 236-240 and 283-287 ka, respectively. Thouveny et al. (2004) identified one excursion in this interval from deep-sea cores off the coast of Portugal, which they called the Portuguese Margin excursion at $\sim 290 \mathrm{ka}$. Channell (2017) identified an excursion from deep-sea sediments of the NW Atlantic Ocean (Orphan Knoll) with an age of $286 \mathrm{ka}$. He named that excursion the Portuguese Orphan excursion.

A summary of these excursion records indicates evidence for at least two excursions. One excursion, named $8 \alpha$, is best dated at 236-240 ka. The second excursion, named $9 \alpha$ or Portuguese 

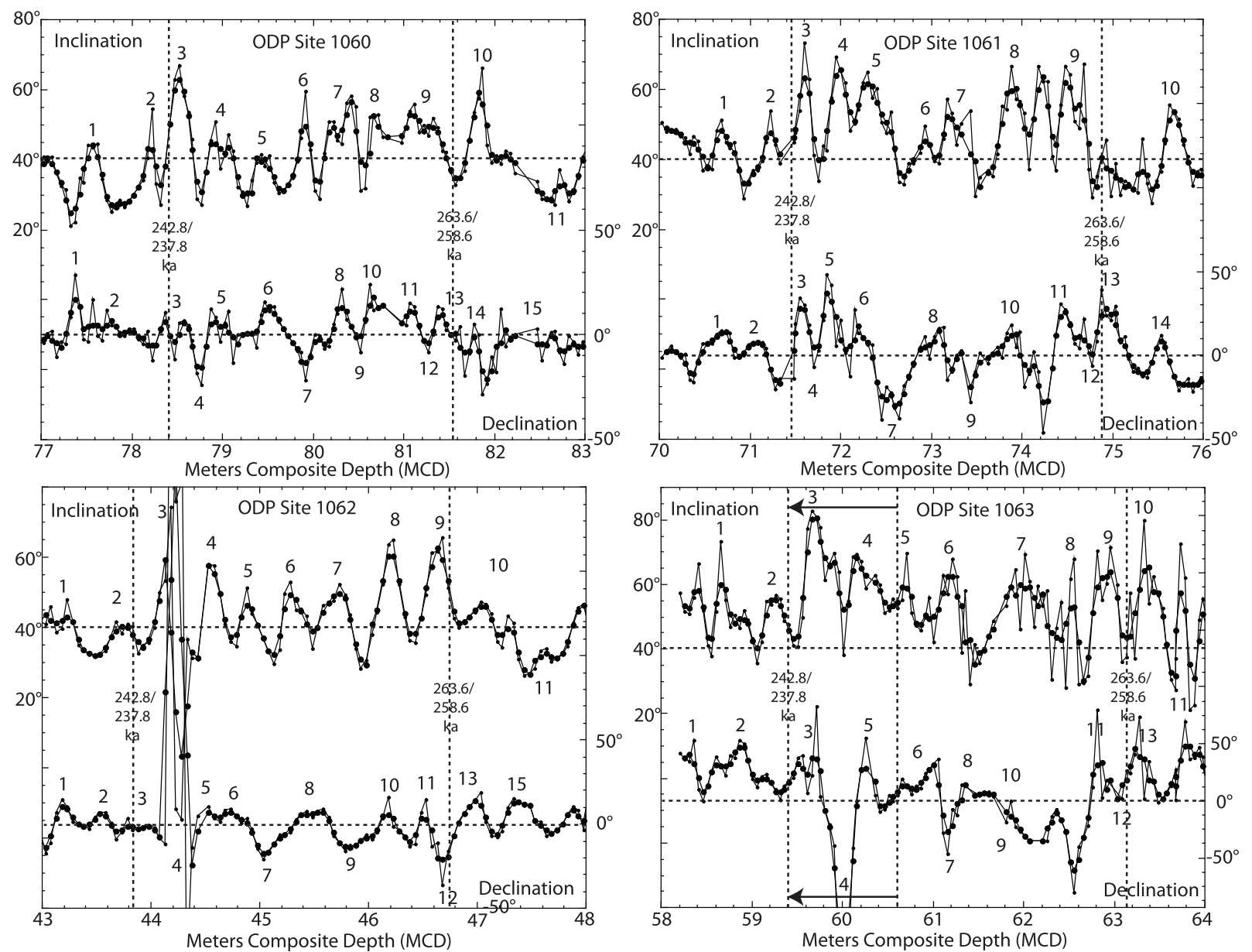

Figure 1. MIS 8 (youngest 1/3 interval) directional palaeomagnetic secular variation (inclination and declination) composite records for ODP sites 1060-1063 plotted versus depth (metres composite depth-mcd). Grutzner et al. (2002) isochrons (both tuned and phase-shifted) are plotted with vertical dashed lines. Correlatable inclination and declination features are numbered.

Orphan, is best dated at 283-287 ka. Excursion records noted by Nowaczyk \& Baumann (1992) and Nowaczyk et al. (1994) near $250 / 260$ ka may be the same as Excursion $8 \alpha$. Their chronologies are not good enough to say that they are separate excursions from $8 \alpha$ and their palaeomagnetic records do not contain a separate excursion synchronous with Excursion $8 \alpha$. However, these excursion records occur at sites that also contain the $9 \alpha$ /Portuguese Orphan excursion below them. The remaining excursion record is that of CR0 dated at $261 \pm 3 \mathrm{ka}$ (Langereis et al. 1997). The chronology of this excursion record is very good and suggests that it is significantly different in age from Excursion $8 \alpha$ or $9 \alpha$ /Portuguese Orphan. It may be that the two excursion records at $\sim 250 / 260$ ka of Nowaczyk \& Baumann (1992) and Nowaczyk et al. (1994) can be correlated to excursion CR0. However, the evidence for a third excursion in the MIS 8 time interval, excursion CR0 at $261 \pm 3 \mathrm{ka}$, is still tenuous.

\section{DEVELOPMENT OF PSV RECORDS}

Long-core palaeomagnetic measurements at $5-\mathrm{cm}$ resolution were made on the archive halves of all cores collected during ODP Leg 172 (Keigwin et al. 1998). Normally, at least three holes were drilled at each site to guarantee that a complete, composite section of deepsea sediments was recovered (Keigwin et al. 1998). The natural magnetic remanence (NRM) of cores from at least one hole at each site was measured and then each core was stepwise demagnetized at one or two steps in alternating magnetic fields (af) at 10 or $20 \mathrm{mT}$. The cores at other holes from the same site were routinely just demagnetized and measured after 20-mT af demagnetization. The palaeomagnetic records from sites 1060-1063 were the only ones to routinely record evidence of any magnetic field excursions (Lund et al. 1998, 2001a) for reasons we will discuss in more detail below. Therefore, this analysis will be limited to those four sites.

Site 1060, situated at $3481 \mathrm{~m}$ water depth on the Blake Outer Ridge, has three Brunhes PSV records from Holes A, B and C. Site 1061, situated at $4045 \mathrm{~m}$ water depth from the Blake Outer Ridge, has three Brunhes PSV records from Holes A, C and D. Site 1062, in 4762-m water depth from the Bahama Outer Ridge, has seven Brunhes PSV records from Holes A-F and H. Four of these holes, Holes A-D, are on the east side of a mud wave (Keigwin et al. 1998) and have higher sediment accumulation rates than Holes E, F and $\mathrm{H}$ from the west side of the mud wave. Our analysis focuses on Holes A-D. Site 1063, situated at $4584 \mathrm{~m}$ water depth on the Bermuda Rise, has four Brunhes PSV records from Holes A-D.

PSV records from all holes at one site were intercompared using the shipboard-derived depth system, metres composite depth (mcd), that relied on correlation of selected sedimentologic parameters, most routinely magnetic susceptibility $(5-\mathrm{cm}$ measurement interval), among all the holes to correct depth measurements for any one core segment at one hole relative to the other core segments 

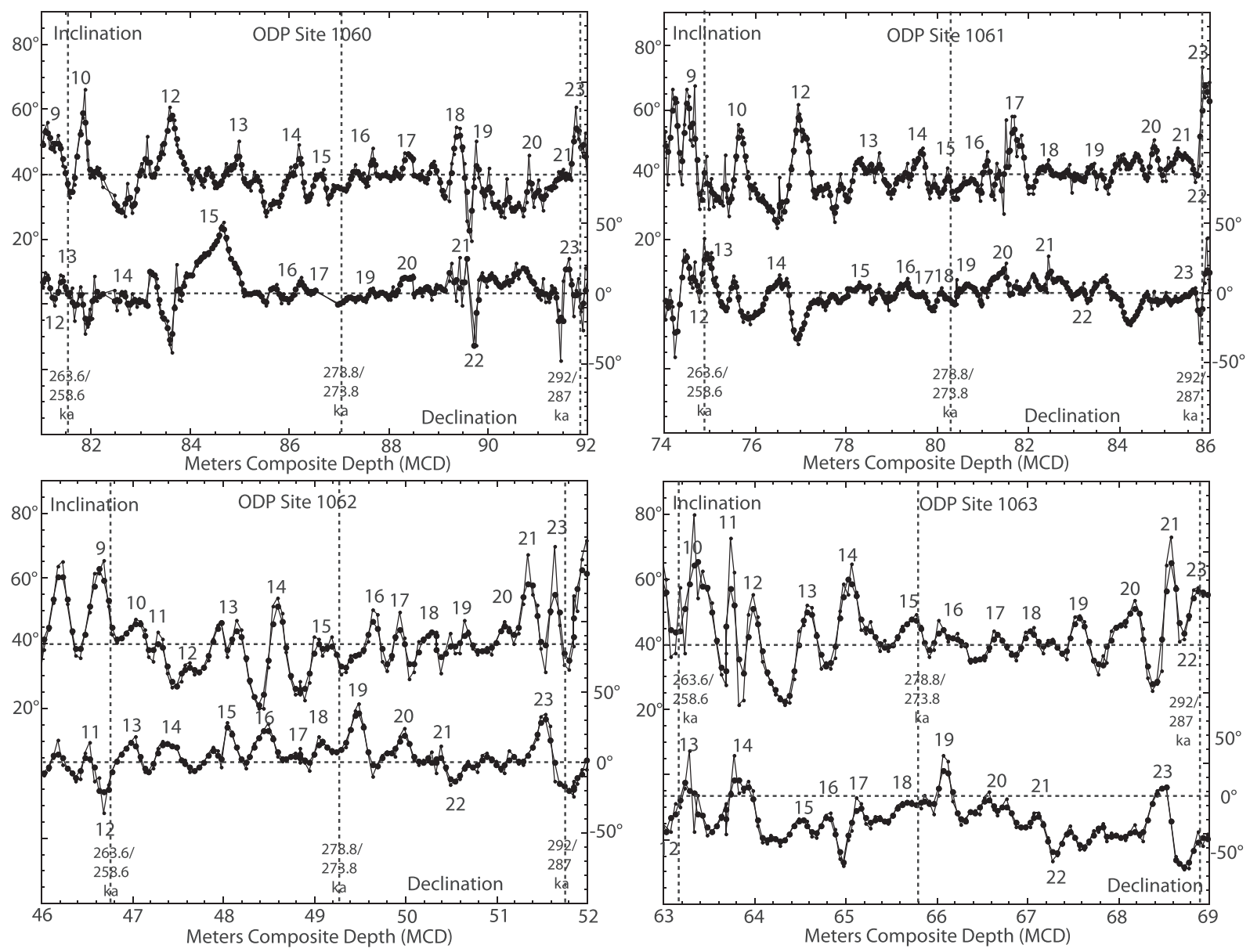

Figure 2. MIS 8 (middle 1/3 interval) directional palaeomagnetic secular variation (inclination and declination) composite records for ODP sites $1060-1063$ plotted versus depth (mcd). Grutzner et al. (2002) isochrons (both tuned and phase-shifted) are plotted with vertical dashed lines. Correlatable inclination and declination features are numbered.

at other holes. (Our new magnetic correlations, described below, are more detailed than the shipboard med determinations, such that individual, synchronous PSV features may vary in med depth among the holes at one site by up to $20-30 \mathrm{~cm}$.)

Our PSV correlations among holes at one site were developed by comparing palaeomagnetic records of inclination, declination, relative palaeointensity and magnetic susceptibility. Relative palaeointensity was determined by dividing NRM intensity after 20-mT af demagnetization (NRM20) by magnetic susceptibility. The goal was to identify features in each of these parameters that were correlatable among holes and assess the extent to which they were synchronous with other parameters. We routinely found that all four parameters were synchronous in their variability among all the holes at each site to within $\pm 5 \mathrm{~cm}$, the limit of our sampling/measurement resolution.

After assessing the degree of correlation among all the holes at one site, we compared the individual inclination, declination or relative palaeointensity records to look for common features. This process also identified 'anomalous' measurements in any parameter from one hole that were not present in the other holes. Such 'anomalous' measurements were edited out from the individual records. Such measurements constituted less than 2 per cent of all the measurements. We attribute these anomalous measurements to either random 'errors' in the measurement process or random sediment disturbances in individual holes due to minor turbidites or sampling process that were not common to other holes at one site. Finally, all of the individual parameters were intercompared to develop a composite record of PSV for each site.

Another method of PSV analysis is to recover u-channels of sediment from the archive half of individual cores and carry out a more detailed (1-cm measurement resolution) set of magnetic measurements on them. We have previously carried out such an analysis on selected u-channels (Lund et al. 2001a,b) from ODP Leg 172 and determined that u-channel palaeomagnetic measurements routinely replicate the shipboard measurements. Below, we will describe u-channel measurements from selected intervals around excursion records within MIS 8 that also have surrounding PSV and show that they are both comparable to the shipboard measurements.

\section{COMPARISON OF SHIPBOARD PSV RECORDS}

The starting point for our comparison of PSV among sites 10601063 is the chronostratigraphic synthesis of Grutzner et al. (2002). They compared the calcium carbonate records from all of the ODP Leg 172 sites and tuned them by comparison with astronomical Milankovich cyclicity (orbital parameters precession and obliquity). Their results for the time interval surrounding MIS 8 are 

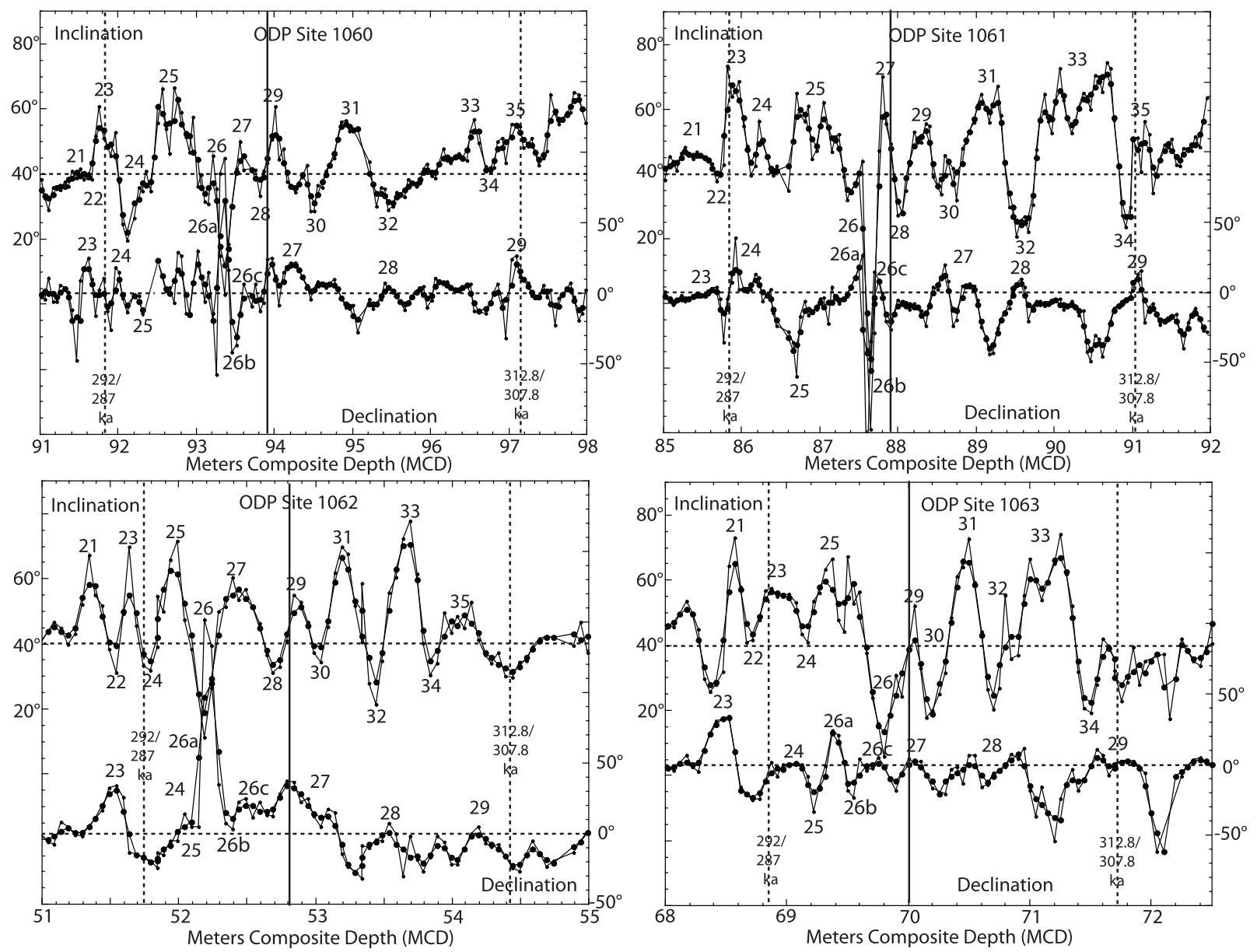

Figure 3. MIS 8 (oldest $1 / 3$ interval) directional palaeomagnetic secular variation (inclination and declination) composite records for ODP sites $1060-1063$ plotted versus depth (mcd). Grutzner et al. (2002) isochrons (both tuned and phase-shifted) are plotted with vertical dashed lines. Correlatable inclination and declination features are numbered.

summarized in Table 1 . They identify five isochrons between 242.8 and $312.8 \mathrm{ka}$, which surround MIS 8 (243-300 ka). Grutzner et al. (2002) also considered the phase lag between orbital forcing and climate response (Imbrie \& Imbrie 1980). They saw little difference between tuned ages and palaeoclimate age estimates. Consequently, they used a $5 \mathrm{ka}$ offset (phase shift; Imbrie et al. 1984) as their final age estimates for each horizon (Table 1). We have used these five isochrons (both the tuned ages and their $5 \mathrm{ka}$ phase shift) as a template upon which to correlate and date our PSV records. These five isochrons (referred hereafter as Grutzner isochrons) provide a starting point, as well, for considering the quality/resolution of our PSV records. Table 1 shows the average sediment accumulation rates between each pair of isochrons for all four sites. The four sites range from $\sim 16$ to $30 \mathrm{~cm} \mathrm{kyr}^{-1}$ in sediment accumulation rate within MIS 8 . Such rates are normally associated with medium-resolution (10$20 \mathrm{~cm} \mathrm{kyr}^{-1}$ ) to high-resolution (>20 $\mathrm{cm} \mathrm{kyr}^{-1}$ ) palaeomagnetic secular variation records.

At each site, we developed a 'PSV splice' that is a single composite record of PSV for each site that weaves selected intervals of directional variability from individual holes. Each interval of PSV from a single hole was chosen as the best example of PSV from all the holes at one site and represents the 'normal' pattern seen in all the holes. Such splices have been routinely developed for a variety of proxies from ODP Leg 172 (Keigwin et al. 1998). Appendices 1-4 contain the MIS 8 full-vector PSV records from all four sites.
Figs $1-3$ plot the directional PSV (inclination and declination) of the PSV splices for each of our study sites. Each figure focuses on about one-third of the total MIS 8 time interval and is defined by two or three of the Grutzner isochrons (vertical dashed lines in Figs 1-3). The figures all have selected inclination and declination features, numbered for ease of comparison, which we correlate among all four sites. (The correlations we describe also include relative palaeointensity data, see below, and the correlations are synchronous among all three palaeomagnetic parameters in all cases.) This is the first time that long PSV records from times older than the last glacial cycle have been so correlated/compared on a regional scale $(>1000 \mathrm{~km})$. There are 35 correlatable inclination features and 29 correlatable declination features in the four PSV records. The numbered features are shown in Figs 1-3.

Excursion $8 \alpha$ (Fig. 1) is the PSV interval of inclination features 3-4 and declination features 3-5. All holes from Sites 1062 and 1063 contain true excursional directions in this interval (unless the time window occurs at a core boundary, e.g. Hole 1063C). The Site 1062 records have the 'best' records of the excursion, based on their reproducible character of data from all holes (see more detailed discussion below). Data from Site 1063 have Excursion $8 \alpha$ at a different stratigraphic depth relative to the Grutzner isochrons than do records from the other three sites. We think that this isochron ( $242.8 \mathrm{ka}$ at $60.3 \mathrm{mcd}$ ) is incorrectly placed, relative to its placement at the other three sites, and should be located at $59.3 \mathrm{mcd}$ (see 

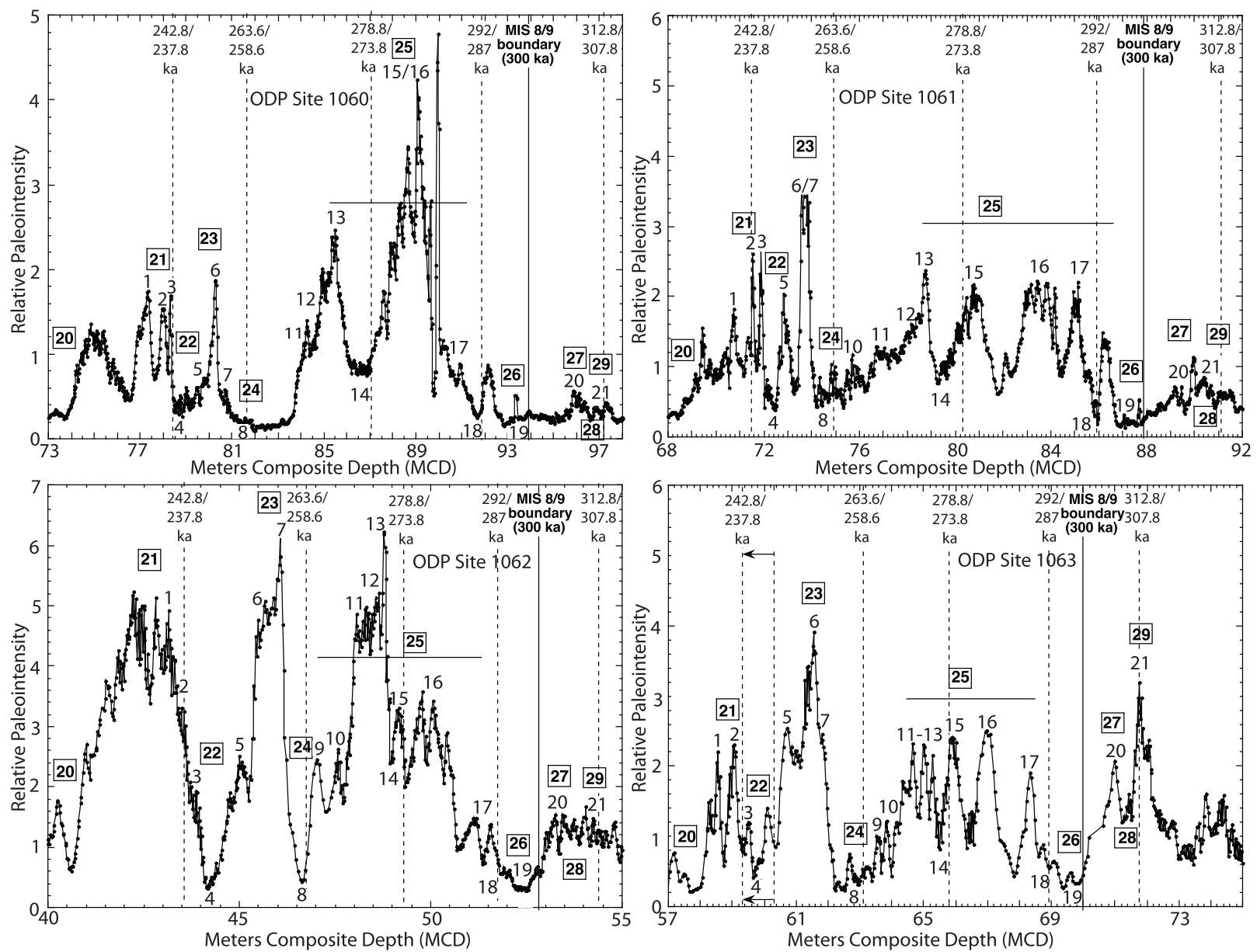

Figure 4. MIS 8 relative palaeointensity records for ODP sites 1060-1063. Grutzner et al. (2002) isochrons (both tuned and phase-shifted) are plotted with vertical dashed lines. 21 (unboxed) correlatable palaeointensity highs and lows are numbered in the four records. Selected palaeointensity features are also correlated with the PISO-1500 palaeointensity record of Channell et al. (2009; Fig. 5) and labelled with boxed numbers 20-29.

arrows and revised vertical dashed line in Fig. 1). All other Grutzner isochrons (Figs 1-3) appear to be synchronous among all four sites to within $\pm 20 \mathrm{~cm}(\sim 1000 \mathrm{yr})$.

A second excursion that we had previously labelled as Excursion $9 \alpha$ and thought that it was in MIS 9 is associated with inclination features 25-27 and declination features 26a, b, c (Fig. 3). Again, all holes at Site 1062 contain true excursional directions, but only one hole each at Sites 1060 and 1061 contains true excursional directions and none of Site 1063 sites contain true excursional directions [although Channell et al. (2012a) concur that this is an excursional interval]. The new chronostratigraphy of Grutzner et al. (2002) places this excursion within the oldest part of MIS 8. [Fig. 3 vertical solid lines are the MIS 8/9 boundary at each site according to Grutzner et al. (2002)]. We originally named excursion records for ODP Leg 172 by the stage in which they occurred (Lund et al. 1998,2001 a) with younger excursions within a single stage being labelled as ' $\alpha$ ' and older excursions in the same stage being labelled as ' $\beta$ ', etc. By this nomenclature, this excursion should be ' $8 \beta$ ', but we choose, for simplicity, to continue calling it $9 \alpha$ '.

The relative palaeointensity variability for all four sites is plotted in Fig. 4. We note 21 correlative palaeointensity highs/lows (unboxed numbers) in these four records. All are consistent with the directional correlations noted above. We can also compare this sequence with the global palaeointensity stack, PISO-1500, of Channell et al. (2009), which is shown in Fig. 5 (last 400 ka only). We have identified 10 features from PISO-1500, intensity features 2029 (Fig. 5), in our records and labelled them within boxes in Fig. 4. We have correlated our palaeointensity highs/lows to PISO-1500 using the youngest and oldest Grutzner ages (shown as pairs of solid vertical lines in Fig. 5). Grutzner age 242.8/237.8 ka (tuned/phase shifted) lies at the top of palaeointensity low 4 at all sites. Fig. 5 shows that Grutzner age lies within palaeointensity low 22. We, therefore, associate our palaeointensity low 5 with PISO-1500 low 24. Grutzner age $312.8 / 307.8$ ka lies within our palaeointensity high 21 ; it is equivalent to PISO-1500 palaeointensity high 29 in Fig. 5. The intervening highs/lows can be easily correlated on that basis and are the boxed numbers in Fig. 4. These correlations are consistent with the palaeomagnetic studies of Channell et al. (2012a) on ODP site 1063.

\section{REVISED CHRONOSTRATIGRAPHY FOR MIS 8}

The relative palaeointensity records provide an independent age model for the ODP Leg 172 sites, distinct from the analysis of Grutzner et al. (2002). The relative palaeointensity variability of Channell et al. (2012a) is identical to that which we have obtained (Fig. 4). The oxygen isotope variability of Channell et al. (2012a) is also not significantly different from the oxygen isotope variability 


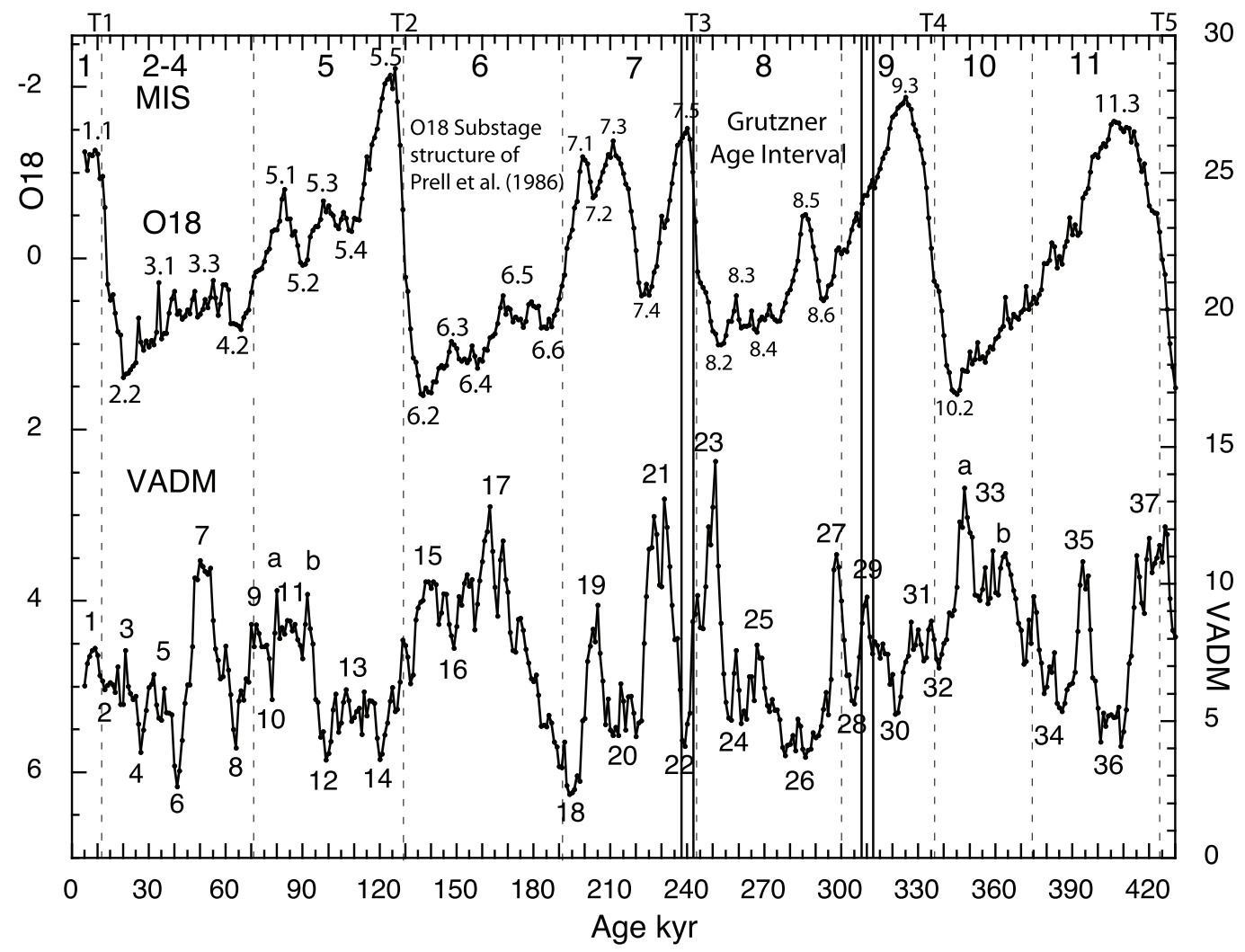

Figure 5. PISO-1500 palaeointensity record and associated oxygen isotope record of Channell et al. (2009) for the last 400 ka. MIS 8 bounding age markers from Grutzner et al. (2002) are shown by vertical solid lines (both tuned and phase-shifted ages). Distinctive palaeointensity highs/lows are labelled. These can be correlated with our palaeointensity records in Fig. 4.

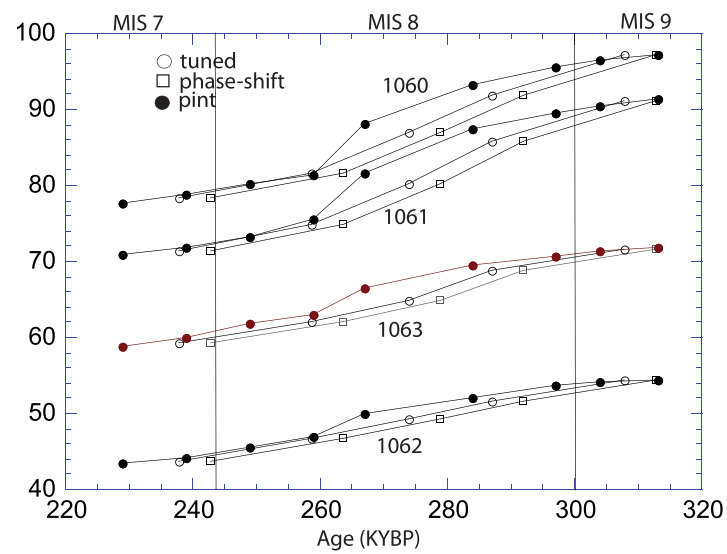

Figure 6. Time/depth plots of ODP sites 1060-1063 using three different chronostratigraphic estimates-tuned and phase-shifted isochrons of Grutzner et al. (2002) and selected PISO-1500 palaeointensity features (referred to herein as PINT) from Channell et al. (2009). These ages are also listed in Table 1.

of Channell et al. (2009), which is plotted against relative palaeointensity in PISO-1500 (Fig. 5).

Table 1 also summarizes an independent chronostratigraphy (PINT) for sites 1060-1063 based on the PISO-1500 record of Channell et al. (2009). We have identified nine palaeointensity highs or lows (21-29) (Figs 4 and 5; Table 1). We also have calculated the average interval sediment accumulation rates for all sites
(Table 1). In general, these are comparable to those estimated by Grutzner et al. (2002), although our PINT age estimates indicate higher sediment accumulation rates within MIS 8 (a glacial interval) than those rates based on Grutzner et al. (2002) ages.

The time/depth variability for all four sites using separately the Grutzner et al. (2002) ages (both tuned and phase-shifted) and palaeointensity ages from PISO-1500 (Fig. 6) reveals that all three methods yield similar ages at the stage boundaries $( \pm 1-2 \mathrm{ka})$, but differ more significantly within MIS $8( \pm 3-5 \mathrm{ka})$. We prefer to use the chronology estimated by the palaeointensity correlations with PISO-1500. Variations in palaeomagnetic age versus stratigraphic age due to variations in bioturbation/sediment palaeomagnetic lock-in cannot account for the $\pm 3-5$ ka offsets noted between the two dating schemes. Offsets due to variations in bioturbation/palaeomagnetic lock-in (typically $5-10 \mathrm{~cm}$ in our deep sites) may cause age offsets less than $500 \mathrm{yr}\left(20-30 \mathrm{~cm} \mathrm{kyr}^{-1}\right.$ sedimentation rate) in all cores.

A separate issue is the absolute ages of the MIS 8 stage boundaries. The MIS 8 termination is also glacial Termination III, which is well dated by Lisiecki \& Raymo (2005) as ca. $243 \mathrm{ka}$. But, the MIS 8 onset, a glacial onset, is not as well defined. The boundary should be below oxygen isotope substage 8.5 of Prell et al. (1986). That should place the boundary at $\sim 300 \mathrm{ka}$, between palaeointensity highs 27 and 29 of PISO-1500 (Fig. 5). However, Channell et al. (2012b) place the MIS $8 / 9$ boundary at $280 \mathrm{ka}$ and above oxygen isotope substage feature 8.5 in deep-sea sediments of the Labrador Sea (their fig. 6). Channell et al. (2012a) also place the MIS 8/9 boundary at $\sim 67.6 \mathrm{mcd}$ in Site 1063 (their fig. 17) which is above 

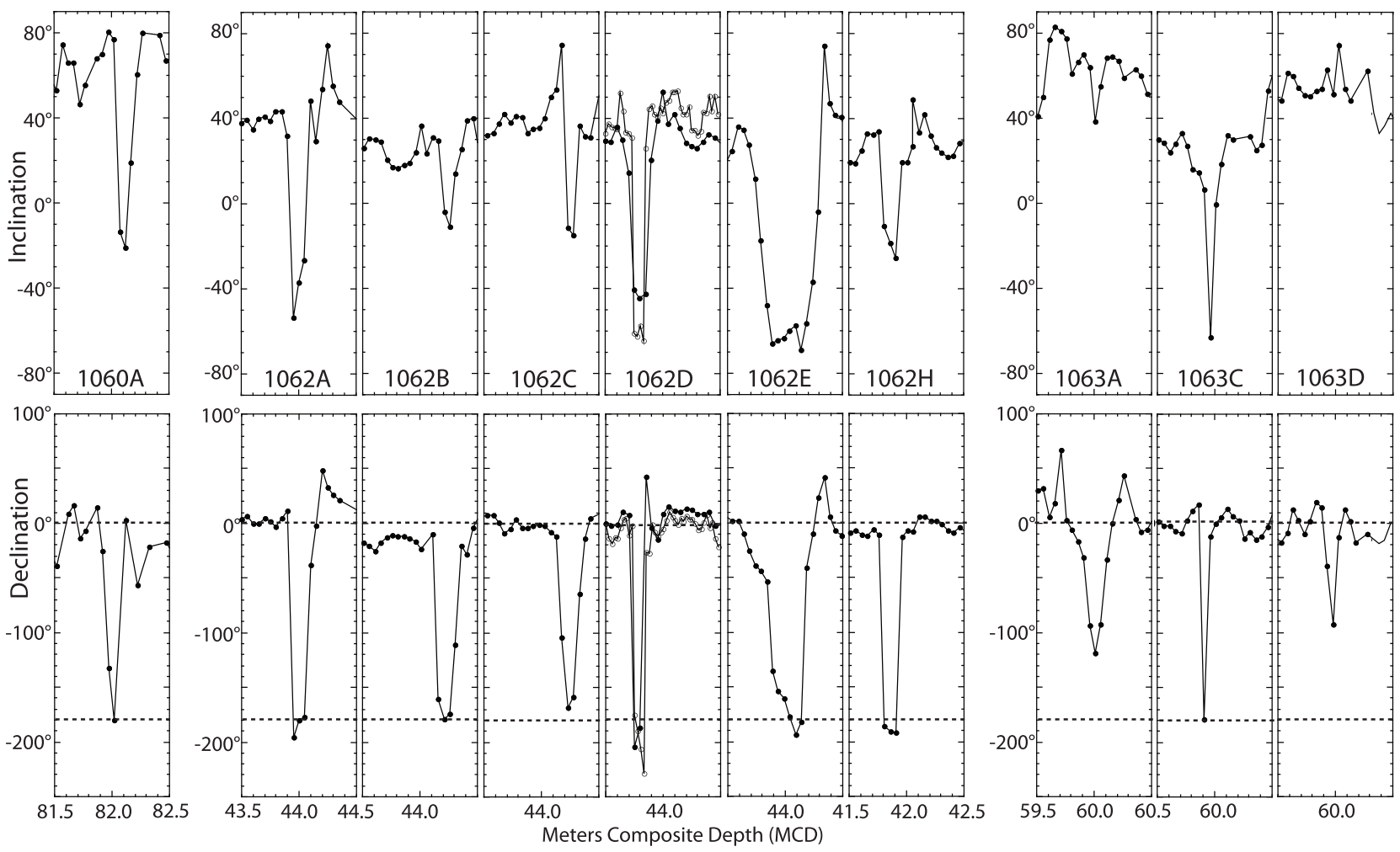

Figure 7. Palaeomagnetic directions for each ODP Site 1060-1063 core that recorded Excursion $8 \alpha$ and its surrounding PSV.

feature 8.5 (their fig. 2) and above palaeointensity 26 (their fig. 4). We argue that these placements are wrong and that the MIS 8/9 boundary is at $\sim 300 \mathrm{ka}$ and between PISO-1500 palaeointensity highs 27 and 29. Below, we use the palaeointensity (PISO-1500) timescale to carry out time-series analysis on the PSV.

\section{CHARACTER OF MIS 8 EXCURSIONS}

The shipboard measurements of Excursion $8 \alpha$ show that all holes at sites 1062 and 1063 have true excursional directions (Fig. 7), unless the excursion interval is in a core gap (1063B). Individual holes at any of our studied sites may not record excursions due to local variations in sedimentation rate, bioturbation interval or just poor remanence acquisition. Slower sedimentation rates or thicker intervals of bioturbation will smear out the details of excursional variability or simply erase it. Site 1062 seems to have the most detailed and most reproducible record of Excursion $8 \alpha$. At that site, there is a clear sense of both inclination and declination changing quickly and in phase from normal polarity directions to reverse polarity directions. In fact, the average normal polarity inclination near the excursion is almost exactly the same inclination, but opposite in sign, as that which occurs in the excursion interval itself. Similarly, the normal polarity declinations appear to be close to $0^{\circ}$, while the excursion declinations average $\sim 180^{\circ}$ (full reversal). Shipboard discrete measurements of the excursion interval in Hole 1062D (Fig. 7, open circles; Keigwin et al. 1998; Lund et al. 1998) show the same pattern. Similarly, u-channel measurements of the excursion interval in Hole 1062C also show a complete reversal. We think the evidence is quite clear that excursion $8 \alpha$ is a local full reversal of the field (Class II excursion; Lund et al. 2005). The key features of Class II excursions is in-phase variation in inclination and declination during the excursion and directions that indicate a near full-reversal of the local palaeomagnetic field.

The age of Excursion $8 \alpha$ is more problematic. Our shipboard data suggest that the excursion was located near the middle of MIS 8 (Keigwin et al. 1998; Lund et al. 1998, 2001a). Our revised palaeointensity chronology associates the excursion with palaeointensity low 22 (Fig. 5) of PISO-1500. The centre of that palaeointensity low is at about 239 ka near the base of MIS 7. We estimate the excursional interval of Excursion $8 \alpha$ to be $236.7-$ $239.8 \mathrm{ka}$.

There are fewer sites with shipboard measurements of Excursion $9 \alpha$. Only Site 1062 yields excursional directions in all holes, unless the excursion occurs in a core gap (1062D, 1062H). Site 1062A may contain the 'best' record of the excursion. The character of the directional variability within the excursion seems fundamentally different from that of Excursion $8 \alpha$. Excursion $9 \alpha$ appears to have out-of-phase variations in inclination and declination. The dashed lines in Fig. 8 indicate the maximum deviation in inclination for each hole; the declination east/west swings in almost all cases appear to be out-of-phase with respect to the inclination highs/lows. This is the pattern we have previously documented for the Laschamp Excursion (Lund et al. 2005) and termed Class I excursions. Class I excursions show anomalous directions that are out-of-phase in their inclination and declination variability and tend not to have directions that reach full polarity reversal.

The age of Excursion $9 \alpha$ is also problematic. It was associated with MIS 9 based on shipboard studies (Keigwin et al. 1998; Lund et al. 1998, 2001a). Our revised palaeointensity chronology associates the excursion with palaeointensity low 26 (Fig. 5) of PISO-1500. The centre of that palaeointensity low is at $284 \mathrm{ka}$. The palaeointensity places Excursion $9 \alpha$ within MIS 8. We 

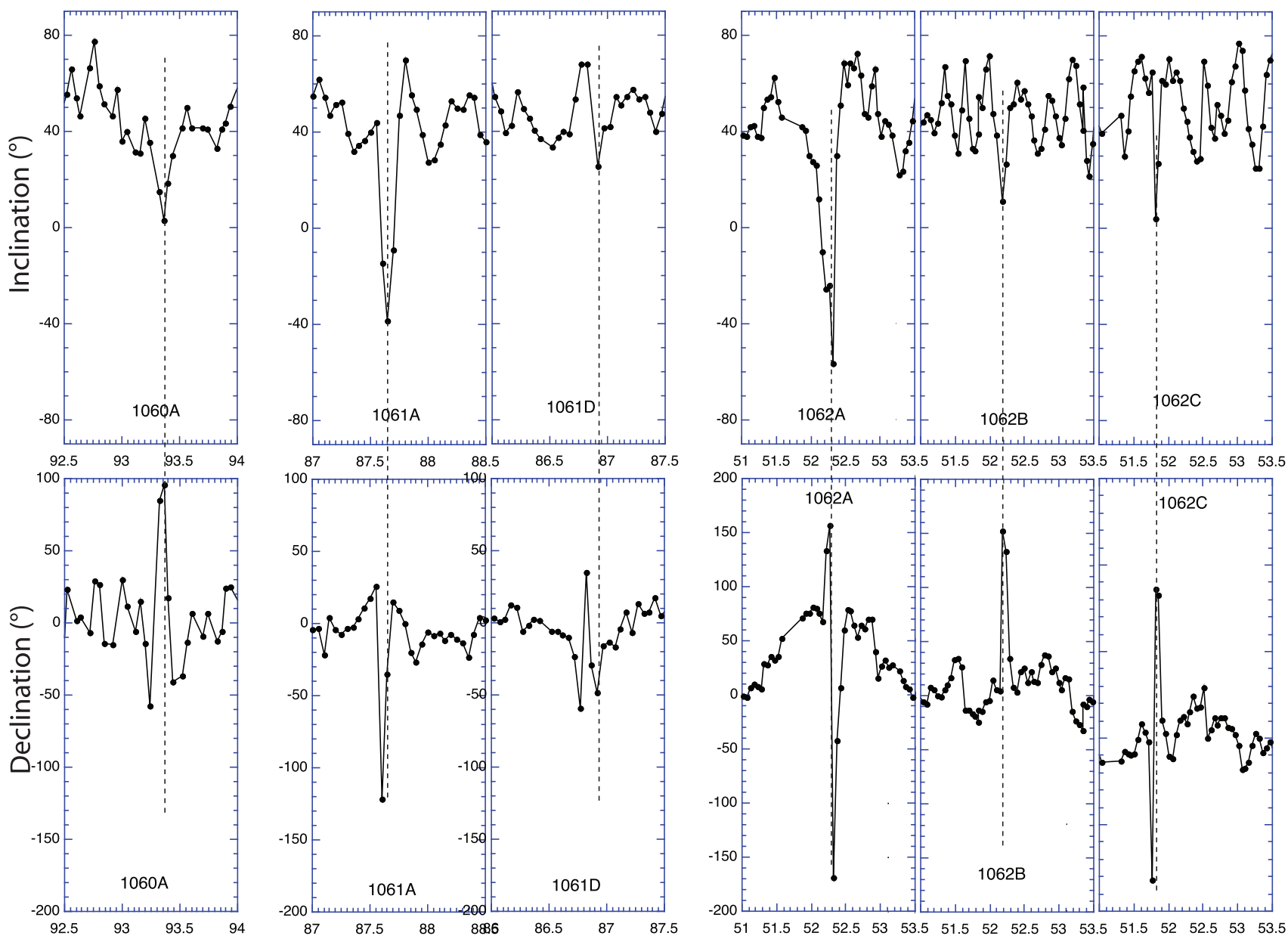

Figure 8. Palaeomagnetic directions for each ODP Site 1060-1063 core that recorded Excursion $9 \alpha$ and its surrounding PSV.

date the excursional interval of Excursion $9 \alpha$ between 283.7 and $286.9 \mathrm{ka}$.

\section{LONG-TERM PSV DURING MIS 8}

Lund (2018) has developed a new method of statistical analysis for well-dated long-term full-vector PSV records. The scalar inclinations, declinations, unit vectors and palaeointensities are averaged in $3 \mathrm{kyr}$ windows with $1.5 \mathrm{kyr}$ overlap and in $9 \mathrm{kyr}$ windows with $4.5 \mathrm{kyr}$ overlap. The analysis is carried out after removal of all true excursional directions (virtual geomagnetic poles, VGPs, more than $45^{\circ}$ from the North Pole). This type of statistical analysis requires good millennial-scale chronostratigraphic control on the PSV records. This shorter-interval statistical analysis is geared to assess the pattern of 'normal' PSV associated with regional dynamo activity.

The directional results of our statistical analysis (Fig. 9) are averages of inclinations, declinations and angular dispersion in 3- and 9-ka windows plotted versus time with $1 \sigma$ uncertainties. There is no significant difference between the scalar inclination or declination averages versus the unit-vector averages. There is strong serial correlation among the statistical values in successive intervals and the $3 \mathrm{ka}$ and $9 \mathrm{ka}$ highs/lows are synchronous. The overall average inclinations are near axial-dipole expectation $\left(\sim 44^{\circ}\right.$ for Sites $1060-1062, \sim 47^{\circ}$ for Site 1063).
The $3 \mathrm{ka}$ inclination and declination averages for Sites 1060 1062 vary by up to $25^{\circ}$; the $9 \mathrm{ka}$ averages vary up to $20^{\circ}$. The averages for Sites 1063 are about $5^{\circ}$ higher. This may be due to its significantly different location $(\sim 1000 \mathrm{~km}$ offset) versus the other three sites. These values suggest that there is significant PSV on timescales of 3-9 ka. The pattern of inclination variability is strongly correlated among the four sites. Fig. 9 shows 10 correlative highs/lows (labelled A-J) at the four sites. There is a similar strong serial correlation in the declinations with 11 correlative high/lows (labelled A-K) at all four sites.

The directional angular dispersion is also quite variable and strongly correlated among the four sites. There are three synchronous intervals of high dispersion (grey zones of Fig. 9) in all four sites. It is notable that the dispersion variability appears to be bi-modal with intervals of low $\left(\sim 10^{\circ}\right)$ angular dispersion alternating with the three intervals of high dispersion $\left(\sim 25^{\circ}\right)$. More time is spent in the low dispersion mode versus the high dispersion mode. This bi-modal pattern is consistent with the results from Lund (2018) for the last $70 \mathrm{ka}$. There is a general sense of higher inclination and declination variability within the high dispersion intervals, but the correlation is not unique. There are short (3-6 ka) intervals of high directional variability in intervals of low dispersion and vice versa.

The 3 and 9 ka averages of palaeointensity (Fig. 10) show that the pattern of variability is simpler than that of the directions with three distinctive and synchronous palaeointensity lows (PISO-1500 

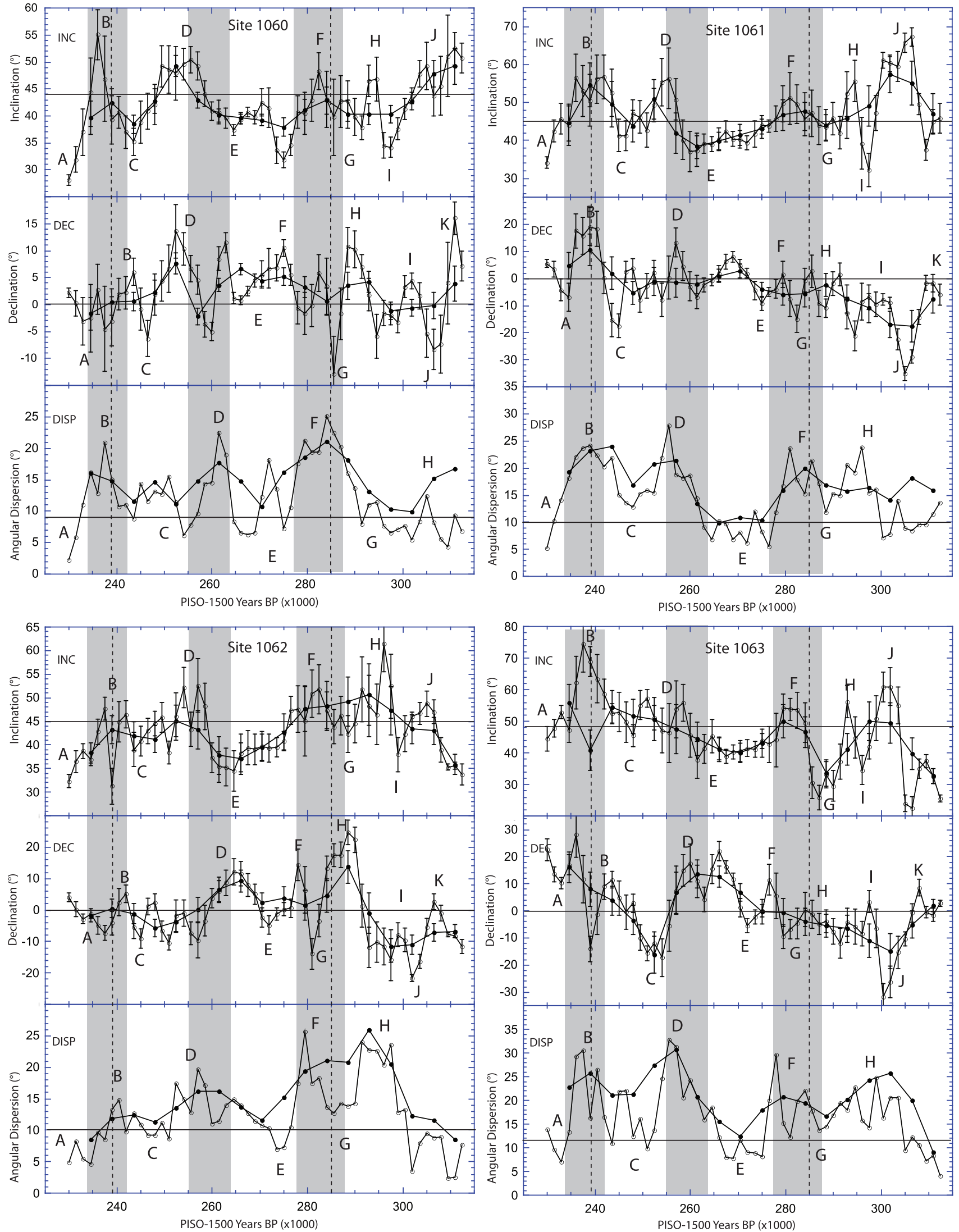

Figure 9. Statistical summary of overlapping 3 and 9 kyr averages for inclination, declination and angular dispersion for Sites 1060-1063 (after removal of all true excursional directions). Vertical lines are $1 \sigma$ uncertainties. Grey intervals are three correlatable zones of high $\left(\sim 25^{\circ}\right)$ angular dispersion. 


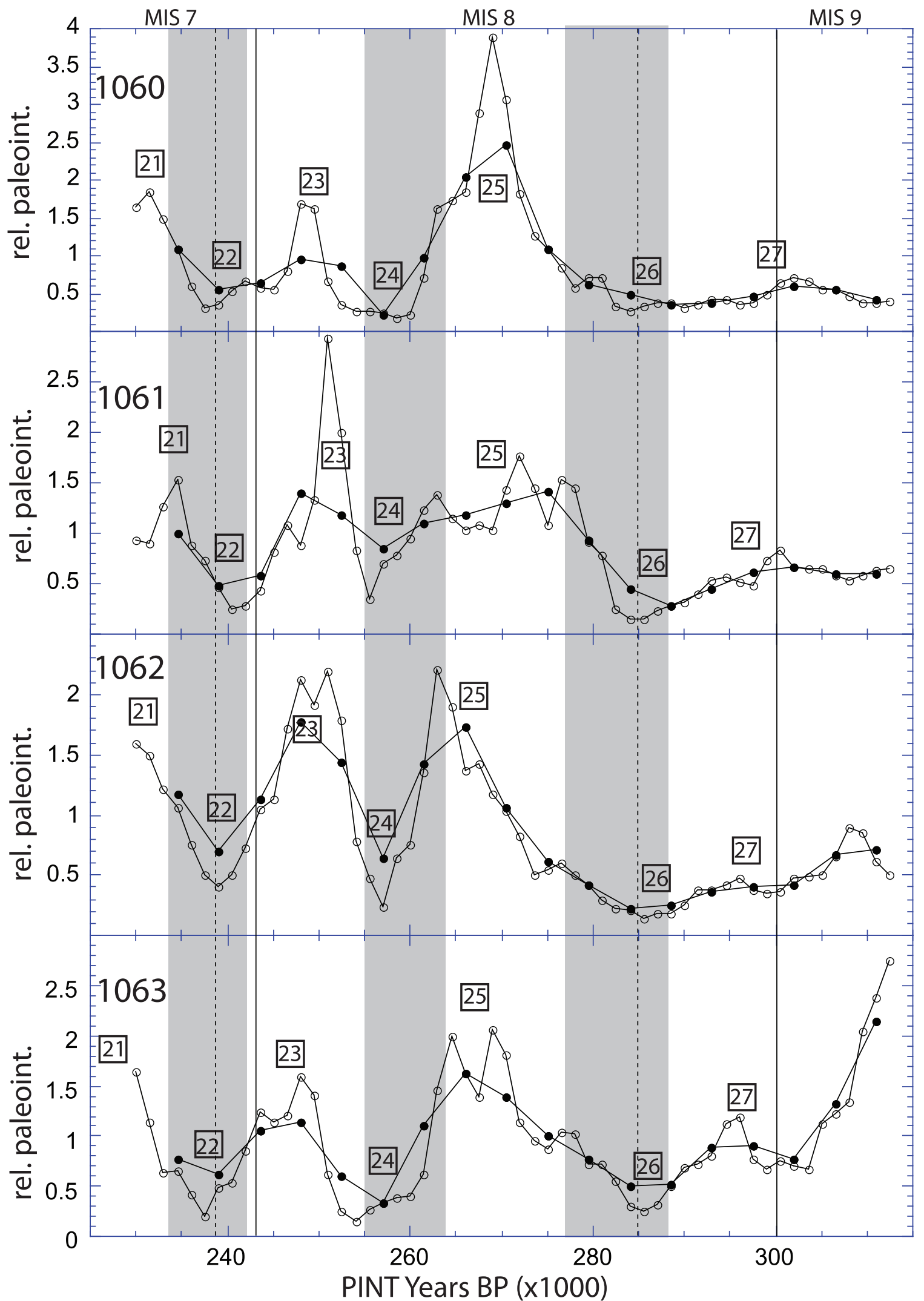

Figure 10. Statistical summary overlapping 3 and 9 ky averages of palaeointensity for Sites 1060-1063. Grey intervals are three correlatable zones of low palaeointensity. These are the same three intervals of high $\left(\sim 25^{\circ}\right)$ angular dispersion shown in Fig. 9. 
lows 22, 24 and 26 in Fig. 5). The three low intensity intervals at these four sites are very similar in how low they are $(\sim 25$ per cent of overall average). These three palaeointensity lows are less equal in PISO-1500 (Fig. 5) with 22 and 26 being significantly lower in intensity than palaeointensity low 24 . Despite the fact that sediment relative palaeointensity estimates are not as accurate as absolute palaeointensity methods (e.g. Merrill et al. 1998), the four sites all reveal the same pattern and suggest that in this region (subtropical North Atlantic Ocean) palaeointensity low 24 was as low as 22 and 26, even though the global averaged record (Fig. 5) shows palaeointensity low 24 being not as low as 22 or 26 .

These three low intensity intervals (grey zones, Fig. 10) are synchronous with the intervals of high angular dispersion (grey zones, Fig. 9) and they are comparable in time span, about 8000$10000 \mathrm{yr}$. This pattern of low palaeointensity associated with high angular dispersion over comparable time spans was also noted for the last $70 \mathrm{ka}$ by Lund ( 2018). It may be that the low-intensity intervals can be associated with a low (poloidal) energy state of the geodynamo that permits larger amplitude directional variability. If true, the million-year averages of angular dispersion may not be representative of the actual pattern of geodynamo activity at any one time. It may be that the 'normal' state of the geodynamo is notably quieter than we usually think, and that the 'low energy' state of the geodynamo may be a distinctive element in defining a prelude to magnetic field excursions or polarity reversals.

\section{RELATIONSHIP BETWEEN MIS 8 PSV AND EXCURSIONS}

The two excursions that we have documented in this study, Excursions $8 \alpha$ and $9 \alpha$, occur within palaeointensity lows 22 and 26 of PISO-1500 and are associated with larger directional variability and angular dispersion. This general relationship between occurrence of excursions, low palaeointensity, larger directional variability and angular dispersion is the same pattern noted for the Mono Lake Excursion (34 ka), Laschamp Excursion (41 ka), and the Greenland Excursion (63 ka) in high-resolution PSV records from around the World (Lund 2018).

It seems that diminishing palaeointensity and increasing directional variability precede excursions, but this relationship is not unique in the PSV records. There are other intervals of diminishing palaeointensity and increasing directional variability that do not precede excursions (e.g. Lund 2018). It is not clear that there is any 'notable' pattern that might uniquely predict the future occurrence of an excursion. There does seem to be continued high directional variability after the excursions until palaeointensity values rise to $>25$ per cent long-term average values. The most notable one-forone correspondence in these PSV records is that between palaeointensity and angular dispersion. The low-palaeointensity/highangular-dispersion intervals may contain excursions, but that does not have to be the case.

\section{DISCUSSION}

This is the first study to evaluate high-resolution geomagnetic field secular variation over an extended time interval ( $\sim 70 \mathrm{kyr})$ older than the last glacial cycle $(0-70 \mathrm{ka})$. The four sites we studied are all located within about $2000 \mathrm{~km}$ of one another. The individual inclination highs/lows and declination east/west extremes are directly correlated among the four sites. This regional PSV pattern is consistent with other estimates that secular variation should be regionally correlatable over a few thousand kilometres. We define
25 cycles of inclination and declination extremes within our study region during MIS 8, for an average of $\sim 2700$ years per cycle.

The directional $3 \mathrm{ka}$ statistics vary significantly with essentially five cycles over $90 \mathrm{ka}$ (Fig. 10) for an average cycle of $\sim 18 \mathrm{kyr}$. This means that two or three successive inclination/declination directional cycles (Figs 1-3) have similar inclination/declination averages, mostly distinct from axial-dipole expectation. This suggests a coherence in the pattern of regional geodynamo variability on a $10^{4} \mathrm{yr}$ timescale and longer. What causes such 'memory' in the geodynamo?

The directional 9 ka statistics also vary significantly with almost four cycles over $90 \mathrm{ka}$ (Fig. 10) for an average cycle of $\sim 22 \mathrm{kyr}$. This also suggests a coherence or 'memory' in the geodynamo process over timescales $>10^{4} \mathrm{yr}$. Overall, PSV likely needs to be averaged over 20-30 kyr to reach successive intervals with approximate axialdipole conditions. This hypothesis has been proposed by a number of palaeomagnetic studies (e.g. Merrill et al. 1998), but has never been tested on high-resolution PSV time-series records.

The essentially bimodal pattern of angular dispersion and its close inverse relationship with palaeointensity appear to be a fundamental characteristic of the geomagnetic field. The fact that palaeointensity variability is largely a globally synchronous process (e.g. Channell et al. 2009; Lund 2018) indicates that the degree of directional variability is also a globally synchronous feature. Future studies of individual high-resolution excursion records on a global scale should address whether excursions, which all occur at basically the same time under conditions of low intensity and high angular dispersion, are independent in style due to regional geodynamo variability or mutually dependent, due to some type of global interconnectivity of the geodynamo process(es).

Our palaeomagnetic data suggest a similar level of PSV quality/detail at all four sites. The bulk sedimentation rates for sites 1060 and 1061 are, however, higher than those for sites 1062 and 1063. Even so, the 'highest-resolution' magnetic excursion records (Fig. 8) occur in the lower sediment accumulation rate sites (sites 1062 and 1063) in significantly deeper water (1062-4762 and 1063$4584 \mathrm{~m}$ ) compared to the higher accumulation rate sites (1060-3481 and 1061-4046 m). One reason for the similarity in PSV detail at all four sites may be that sediment bioturbation (and depth interval of PSV smearing) due to amount of organic matter deposited may be more pronounced at shallower water depths. We hypothesize that the deeper sites have good excursion records because there is less organic matter deposited and thus less sediment bioturbation.

\section{CONCLUSIONS}

Our summary of the pattern of PSV and excursions within MIS 8 (243-300 ka) from the western North Atlantic Ocean ODP sites 1060-1063 shows composite high-resolution PSV records (both directions and relative palaeointensity) developed for each site and intercompared. There are 35 correlatable inclination features, 29 correlatable declination features and 21 correlatable palaeointensity features in the four composite records. All correlatable features are stratigraphically consistent with one another in comparison among sites.

Two methods of chronostratigraphy allow us to date these records, that of Grutzner et al. (2002) who tuned our sediment records with Milankovich cyclicity and that of Channell et al. (2009) who developed the PISO-1500 global palaeointensity record dated with oxygen isotope stratigraphy. The two methods agree well near the MIS 8 stage boundaries but differ up to $\sim 4 \mathrm{kyr}$ in the middle of MIS 8 . We prefer to use the PISO-1500 record to date and analyse our cores. 
There are two excursions in our PSV records-Excursions $8 \alpha$ and $9 \alpha$. Our revised chronology based on comparison with PISO-1500 provides revised ages for both excursions: $8 \alpha(236.7-239.8 \mathrm{ka})$ and $9 \alpha(283.7-286.9 \mathrm{ka})$. This places Excursion $8 \alpha$ at the base of MIS 7 and Excursion $9 \alpha$ in the middle of MIS 8 . We classify Excursion $8 \alpha$ as a 'Class II' excursion (local reversal) with in-phase inclination and declination changes; Excursion $9 \alpha$ is a 'Class I' excursion with $90^{\circ}$ out-of-phase inclination and declination changes.

A statistical study of the PSV records after removing all true excursional directions averages directions and palaeointensity in 3 and $9 \mathrm{ka}$ overlapping intervals to evaluate the space/time character of PSV and its geodynamo cause(s). We see significant PSV directional variability over $10^{4} \mathrm{yr}$ timescales that is regionally correlatable among the four sites. There is a notable pattern of angular dispersion variability with most time spent with low $\left(\sim 10^{\circ}\right)$ dispersion, with three shorter intervals of high $\left(\sim 25^{\circ}\right)$ dispersion. Three notable intervals of low palaeointensity in all four records are easily correlated to PISO-1500. There is a one-to-one correspondence between the three low-palaeointensity intervals and the three intervals of high angular dispersion. The two magnetic field excursions are in two of the three low-palaeointensity/high-dispersion intervals.

\section{DATA AVAILABILITY}

All basic data from this paper are attached as Appendices 1-4. All are excel spreadsheets. Metadata for ODP Leg 172 is available in several ODP publications (Initial Reports, Scientific Results for ODP Leg 172).

\section{REFERENCES}

Champion, D., Lamphere, M. \& Kuntz, M., 1988. Evidence for a new geomagnetic reversal from the lava flows in Idaho: discussion of short polarity reversals in the Brunhes and late Matuyama polarity chrons, $J$. geophys. Res., 93, 11667-11680.

Channell, J.E.T., Xuan, C. \& Hodell, D., 2009. Stacking paleointensity and oxygen isotope data for the last 1.5 Ma (PISO-1500), Earth planet. Sci. Lett., 283, 14-23.

Channell, J.E.T., Hodell, D.A. \& Curtis, J.H., 2012a. ODP Site 1063 (Bermuda Rise) revisited: oxygen isotopes, excursions and paleointensity in the Brunhes Chron, Geochem. Geophys. Geosyst., 13(1), Q02001, doi:10.1029/2011GC003897.

Channell, J.E.T., Hodell, D., Romero, O., Hillaire-Marcel, C., de Vernal, A., Stoner, J.S., Mazaud, A. \& Röhl, U., 2012b. A 750-ky detrital layer stratigraphy for the North Atlantic (IODP Sites U1302-U1303, Orphan Knoll, Labrador Sea), Earth planet. Sci. Lett., 317-318, 218-230.

Channell, J.E.T., 2017. Magnetic excursions in the late Matuyama chron from North Atlantic IODP sites, J. Geophys. Res., 122, 773-789.

Creer, K.M., Hogg, T.E., Readman, P.W. \& Reynaud, C., 1980. Palaeomagnetic secular variation curves extending back to 13400 years BP recorded by sediments deposited in Lac de Joux, Switzerland, J. Geophys., 48, 139-147.

Grutzner, J. et al., 2002. Astronomical age models for Pleistocene drift deposits from the western North Atlantic (ODP Sites 1055-1063), Mar. Geol., 189, 5-23.

Imbrie, J. \& Imbrie, J.Z., 1980. Modeling the climatic response to orbital variations, Science, 207, 943-953.

Imbrie, J. et al., 1984. The orbital theory of Pleistocene climate: support from a revised chronology of the marine $\mathrm{N} 18 \mathrm{O}$ record, in Milankovitch and Climate (Pt. 1), pp. 269-305, eds Berger A., Imbrie J., Hays J., Kukla G., Saltzman B., Plenum Reidel.

Kawai, N., Yaskawa, K., Nakajima, T., Torii, M. \& Horie, S., 1972. Oscillating geomagnetic field with a recurring reversal discovered from Lake Biwa, Proc Jpn Acad, 48, 186-190.
Keigwin, L., Rio, D. \& Acton, G., the ODP Leg 172 Scientific Party, 1998. Initial Results from ODP Leg 172, Ocean Drilling Program, College Station, TX, 172pp.

Langereis, C., Dekkers, M., de Lange, G., Paterne, M. \& van Sanvoort, P., 1997. Magnetostratigraphy and astronomical calibration of the last 1.1 Myr from an eastern Mediterranean piston core and dating of short events in the Brunhes, Geophys. J., 129, 75-94.

Lisiecki, L.E. \& Raymo, M.E., 2005. A Pliocene-Pleistocene stack of 57 globally distributed benthic $\sigma^{18} \mathrm{O}$ records, Paleoceanography, 20, PA1003, doi:10.1029/2004PA001071.

Lund, S.P., 2018. A new view of long-term geomagnetic secular variation, Front. Earth Sci., 6, doi:10.3389/feart.2018.00040.

Lund, S.P., Acton, G., Clement, B., Okada, M. \& Williams, T., 1998. Initial paleomagnetic results from ODP Leg 172: high resolution geomagnetic field behavior for the last 1.2 Ma, EOS, Trans. Am. geophys. Un., 79, $178-179$.

Lund, S.P., , Williams, T., Acton, G., Clement, B. \& Okada, M., 2001a. Brunhes Epoch magnetic field excursions recorded in ODP Leg 172 sediments, in Proceedings of the Ocean Drilling Project, Scientific Results, Vol. 172, eds Keigwin, L., Rio, D. \& Acton, G.., Ocean Drilling Program. Lund, S.P., Acton, G., Clement, B., Okada, M. \& Williams, T., 2001b. Paleomagnetic records of Stage 3 excursions from ODP Leg 172 sediments, in Proceedings of the Ocean Drilling Project, Scientific Results, Vol. 172, eds Keigwin, L., Rio, D. \& Acton, G., Ocean Drilling Program.

Lund, S.P., Schwartz, M., Keigwin, L. \& Johnson, T., 2005. Deepsea sediment records of the Laschamp geomagnetic field excursion ( $<41,000$ calendar years before present), J. geophys. Res., 110, B04101, doi:10.1029/2003JB002943.

Lund, S.P., Stoner, J.S., Channell, J.E.T. \& Acton, G., 2006. A summary of Brunhes paleomagnetic field variability recorded in Ocean Drilling Program cores, Phys. Earth planet. Inter., 156, 194-204.

Merrill, R., McElhinny, M. \& McFadden, P., 1998. The Magnetic Field of the Earth, Paleomagnetism, the Core, and the Deep Mantle, Academic Press, 531pp.

Nowaczyk, N. \& Baumann, M., 1992. Combined high-resolution magnetostratigraphy and nannofossil biostratigraphy for late Quaternary Arctic Ocean sediments, Deep-Sea Res., 39, 567-701.

Nowaczyk, N.R., Frederichs, T.W., Eisenhauer, A. \& Gard, G., 1994. Magnetostratigraphic data from late Quaternary sediments from the Yermak Plateau, Arctic Ocean: evidence for four geomagnetic polarity events within the last $170 \mathrm{ka}$ of the Brunhes Chron, Geophys. J. Int., 117, 453471.

Prell, W.L., Imbrie, J., Martinson, D.G., Morley, J.J., Pisias, N.G., Shackleton, N.J. \& Streeter, H.F., 1986. Graphic correlation of oxygen isotope stratigraphy: application to the Late Quaternary, Paleoceanography, 1, 137-162.

Thouveny, N., Carcaillet, J., Moreno, E., Leduc, G. \& Nerini, D., 2004. Geomagnetic moment variation and paleomagnetic excursions since 400 kyy BP: a stacked record from sedimentary sequences of the Portuguese margin, Earth Sci. Planet. Lett., 219, 377-396.

Wollin, G., Ryan, W. \& Ericson, D., 1971. Magnetism of the Earth and climate changes, Earth Planet. Sci. Lett., 12, 175-187.

\section{SUPPORTING INFORMATION}

Supplementary data are available at $G J I$ online.

\section{Appendix 1: 1060-SPLICE.xls \\ Appendix 2: 1061-SPLICE.xls Appendix 3: 1062-SPLICE.xls Appendix 4: 1063-SPLICE.xls}

Please note: Oxford University Press is not responsible for the content or functionality of any supporting materials supplied by the authors. Any queries (other than missing material) should be directed to the corresponding author for the paper. 